\title{
Early Research on the Biological Effects of Microwave Radiation: $1940-1960$
}

\author{
Harold J. Cook, Nicholas H. Steneck, Arthur J. Vander \\ and Gordon L. Kane \\ The University of Michigan, Ann Arbor, Michigan 48109, U.S.A.
}

Received 8 November 1979

\begin{abstract}
Summary
Two overriding considerations shaped the development of early research on the biological effects of microwave radiation-possible medical application (diathermy) and uncertainty about the hazards of exposure to radar. Reports in the late 1940s and early 1950s of hazards resulting from microwave exposure led to the near abandonment of medical research related to microwave diathermy at the same time that military and industrial concern over hazards grew, culminating in the massive research effort known as 'the Tri-Service program' (1957-1960). Both the early focus on medical application and the later search for hazards played important roles in dictating how this field of research developed as a science.
\end{abstract}

\section{Contents}

1. Introduction

2. Background, 1885-1940: early work on short-waves and therapy ..... 324

3. Early debates over thermal and nonthermal effects.......................... 326

4. The war years and after, 1940-1953: military interest in harmful effects 330

5. Return to therapeutic interest ............................................... 332

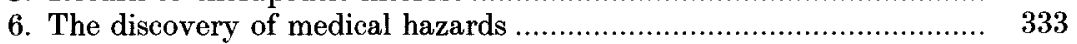

7. Renewed concern, 1953-1957; worries of industry ......................... 335

8. The military response to industrial concern ...................................... 337

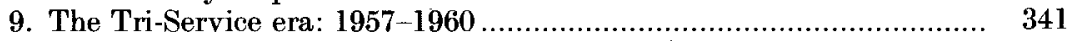

10. Safety standards and the ending of the Tri-Service program .......... 345

11. Conclusions ................................................................................ 348

\section{Introduction}

The history of research on the biological effects of microwave radiation ${ }^{1}$ effectively begins with the development of radar early in World War II, and the concerns that arose thereafter within industrial and military circles over the possible deleterious effects this new source of environmental energy could have on personnel. Prior to this time, the energy levels at which microwaves had been produced were not sufficient to cause widespread concern about harmful effects. Before the invention of radar, artificially produced microwave energy was not a general environmental problem.

\footnotetext{
${ }^{1}$ Microwaves encompass electromagnetic wave radiation falling within the wavelength range of $10^{2}$ $10^{-1} \mathrm{~cm}$ (frequencies of $300 \mathrm{MHZ}-300,000 \mathrm{MHZ}$ ). The microwave range is usually further subdivided into ultra-high $\left(10^{2}-10 \mathrm{~cm}\right)$, super-high $(10-1 \mathrm{~cm})$, and extra-high $\left(1-10^{-1} \mathrm{~cm}\right)$ wavelengths. The standard abbreviations used in this paper are by and large concerned with milliwatts $(\mathrm{mw})$, given in densities per square centimeter $\left(\mathrm{cm}^{2}\right)$. A milliwatt is one-thousandth of a watt, so a tenth of a watt per square centimeter $\left(0 \cdot 1 \mathrm{watt} / \mathrm{cm}^{2}\right)$ equals $100 \mathrm{mw} / \mathrm{cm}^{2}$.
} 
However, as this field of research began to take shape, it did not do so in a vacuum. Well before the invention of radar, medical researchers had been interested in the controlled effect of radio-frequency (rf) energy on living things. Once it was discovered that radio waves could be used to heat body tissue, research was undertaken to study how such heating took place and its effect on the whole organism. As a consequence, both continuity and newness characterize this field of research during its early phase of development.

Between the early 1940s and 1960, research on the biological effects of microwave radiation slowly shifted from its medical context and the search for benefits to a military-industrial context and the search for hazards. The consequence of this shift was twofold. First, it significantly altered the funding patterns and institutional setting in which the majority of research was conducted. Second, it resulted ultimately in the near abandonment of the field when, at the end of the first major research effort on biological effects, the Tri-Service program of the years 1957-1960, those setting policy had solved to their own satisfaction the major problems that concerned them and withdrew their support, leaving the field stranded until new sources for funding were found. It is the objective of this article to trace the development of research on the biological effects of microwave radiation from its beginnings through the end of the Tri-Service era and to draw some general conclusions about the impact of institutional factors on the scientific enterprise. This survey, in combination with our study of the events leading to the adoption of the first microwave standard in 1966 , is designed to provide a comprehensive overview and assessment of the early history of this now controversial area of research. ${ }^{2}$

\section{Background, 1885-1940: early work on short-waves and therapy}

Interest among researchers in the effect of electricity on biological systems arose almost as soon as electricity could be generated in a controlled form. This same interest rapidly shifted to research on the biological effects of electromagnetic radiation when, during the years 1885-1889, Heinrich Rudolf Hertz demonstrated a technique for propagating electromagnetic energy through space. Typical of this shift is the Parisian scientist, Arsene d'Arsonval. Prior to the late 1880s, d'Arsonval had devoted considerable time to the investigation of the physiological effects of electrocution. Shortly after learning about the new Hertzian apparatus, d'Arsonval developed his own equipment, which produced $10^{4}-10^{5} \mathrm{~cm}$ waves at power levels nearing $20 \mathrm{amp}$, and turned his attention to its possible physiological and medical uses. By 1893, he was publishing papers on the influence of radio waves on cells. ${ }^{3}$

Following d'Arsonval's work, efforts continued to generate shorter waves at higher energy and to explore ways of putting these new electromagnetic waves to use in medicine. The primary application to medicine during the early years of the $1900 \mathrm{~s}$

\footnotetext{
${ }^{2}$ The recent interest in the history of the microwave field sparked by Paul Brodeur's controversial book, The zapping of America: microwaves, their deadly risk, and the cover-up (1977, New York), and two earlier articles in The New Yorker (13 and 20 December 1976) has to date not produced any serious investigations of the early years of research. Brief summaries of the early research are given by Don $R$. Justesen, 'Microwaves and behavior', American psychologist, (1975), 394-395; Art Dula, 'Microwave radiation', Jurimetrics journal, 18 (1978), 291-307; S. Baranski and P. Czerski, Biological effects of microwaves (1976, Stroudsburg, $\mathrm{Pa}$. ); and $\mathrm{S}$. Koslov, 'Radio-frequency radiation: the buildup of knowledge against the background of concern' (forthcoming). Our work on the 1966 standard is summarized in 'The origins of safety standards for microwave radiation' (forthcoming).

${ }^{3}$ A. d'Arsonval, 'Influence de l'électricité sur la cellule microbienne', Arch. de physiol. norm. et path., (5), 5 (1893), 66- 69 .
} 
focused on the capacity of rf waves to generate heat in body tissue. The ensuing technique, called 'diathermy' (or 'diathermotherapy') by von Zeyneck in 1908, spread rapidly and was greatly improved by A. W. Hull's invention of the magnetron tube in 1920. Hull's magnetron, which was developed at the General Electric Company laboratories in Schenectady, New York, was capable of producing ultrashort waves (waves under $100 \mathrm{~m}$ were considered short, those in the 3-15 $\mathrm{m}$ range, ultra-short) at higher energy levels. It proved to be a convenient device for inducing local heating in tissue and was adopted as a recognized piece of medical apparatus. ${ }^{4}$

Research on the new, ultra-short waves soon sparked a controversy that has enlivened the microwave field ever since. It was well known by the early 1920 s that rf waves induced local heating, but the question soon arose whether heating was the only effect to be expected. A summary of the results of experiments conducted in France suggested that it was not. In an important article appearing in 1924, A. Gosset, A. Gutmann, G. Lakhovsky and I. Magrou showed that by subjecting tumorous plants to ultra-short wavelengths, the tumors initially grew rapidly and then died. They believed that the effects were not due to heating alone, ${ }^{5}$ thereby sparking new investigations in the United States and elsewhere on what came to be known as 'nonthermal' or 'specific' effects.

The new investigations on nonthermal effects soon began to yield results. Work undertaken in 1924 and reported in 1926 by a surgeon with the United States Public Health Service, J. W. Schereschewsky, detected severe symptoms and lethal effects in mice exposed to ultra-short wave radiation that did not appear to be due to the production of heat. ${ }^{6}$ In 1928 , having taken on a second post in Preventive Medicine and Hygiene at Harvard Medical School, Schereschewsky followed up his earlier studies with published reports that he could destroy malignant tumors in mice, again without much apparent heating. ${ }^{7}$ Such reports prompted a small but significant body of literature attempting to determine the nature of the supposed nonthermal effects.

At about the same time, Erwin Schliephake, working in Germany, found that condenser fields killed small animals such as flies, rats, and mice. These findings were reported in 1928. One year later, while suffering from a painful nasal furuncle, Schliephake turned the field on himself, with the result being the rapid improvement of his condition. As a consequence, he and his colleague in physics, Abraham Esau, began to advocate using short-wave current in the treatment of local pathology. ${ }^{8}$ Their advocacy was taken up by another school of medical researchers who saw possibilities for diathermy in fever therapy.

Fever therapy had as its objective raising a patient's temperature to help the natural forces of the body reject the disease organism. Raising the temperature of patients was, however, sometimes not easily accomplished. Julius Wagner-Jauregg,

\footnotetext{
${ }^{4}$ John Turner, The effects of radar on the human body (U.S. Army Ordnance Missile Command's Liaison Office, Bell Telephone Laboratories, Whippany, N.J., 12 March 1962), Report RM TR 62-1.

${ }^{5}$ A. Gosset, A. Gutmann, G. Lakhovsky and I. Magrou, 'Essai de thérapeutique de 'Cancer experimental' des plantes', Comptes rendus de la Société de Biologie, 91 (1924), 626-628.

${ }^{6} \mathrm{~J}$. W. Schereschewsky, 'The physiological effects of currents of very high frequency $(135,000,000$ to $8,300,000$ cycles per second)', $P u b$. health rep., 41 (1926), 1939-1963.

' J. W. Schereschewsky, 'The action of currents of very high frequency upon tissue cells', $P u b$. health rep., 43 (1928), 927-945.

${ }^{8}$ See E. Schliephake's magnum opus on his new therapeutic techniques: Kurzwellentherapie (1932), translated by King Brown, Short wave therapy (1935, London); and William Bierman and Myron M. Schwarzchild, The medical applications of the short-wave current (1938, Baltimore), 6.
} 
who had pioneered fever therapy in the $1890 \mathrm{~s}$, in 1917 introduced the technique of injecting malaria into patients to cause fever during the treatment of paresis. ${ }^{9}$ Since such bacterial infection had obvious drawbacks, it is not difficult to understand why the medical community welcomed a new therapeutic technique for producing fevers announced by Helen Hosmer of the Department of Physiology of Albany Medical College in 1928. In January of that year she had been called in by W. R. Whitney, director of General Electric's research laboratory in Schenectady, New York, to investigate the headaches and other unpleasant symptoms experienced by technical personnel working with new high-power, short-wave tubes being developed for short-wave radio. She discovered that persons in the immediate vicinity of an operating tube could suffer $2-3^{\circ} \mathrm{F}$ increases in body temperature. Whitney and she knew of fever therapy treatments involving malaria and other types of injections. Hosmer therefore concluded that short-wave radiation might be used as a new method 'for producing at will any degree of fever without the introduction of bacteria, toxins, foreign proteins or other adventitious material or condition into the animal body' ${ }^{10}$

\section{Early debates over thermal and nonthermal effects}

With the introduction of a medically accepted use for diathermy in 1928, the debate over thermal versus nonthermal effects began in earnest. At about this time, the accepted view was becoming more and more, to quote $R$. V. Christie of the Hospital of the Rockefeller Institute for Medical Research, that 'the only constant effect which is known to be produced by high frequency alternating currents is that of heat production'. ${ }^{11}$ Many of the best experimental scientists felt that the reports of Schereschewsky and Schliephake were neither well-controlled nor rigorously checked for heating effects. As early as 1929, Christie and Loomis articulated a position that was repeated many times in the years to come: 'the burden of proof still lies on those who claim any biological action of high frequency currents other than heat production'. ${ }^{12}$

Over the next few years most experiments reported in the literature tended to support the views of Christie and Loomis. Several assumed nonthermal histologic changes were found to be the result of heat (and burns). ${ }^{13}$ Nonthermal effects on

\footnotetext{
${ }^{9}$ For Wagner-Jauregg's contributions, see his remarks in 'Message', in Simpson and Bierman (eds.), Fever therapy: abstracts and discussions of papers presented at the First International Conference on Fever Therapy (1937, New York), 2-4. Fever therapy was advocated in the nineteenth century by Claude Bernard, in his Lectures to the College of France, vol. 4 (1858), 209; and William H. Welch, 'The general pathology of fever', Cartwright Lectures, $M e d$. news, 52 (1888), 365, 393, 539, 565. For later reviews of fever therapy, see W. W. Hall and E. G. Wakefield, 'A study of experimental heat-stroke', J. Am. Med. Assoc., 16 (1927), 177-182; R. R. Sayers and S. J. Davenport, 'Review of literature on the physiological effects of abnormal temperatures and humidities', Pub. health rep., 42 (1927), 933-996; and V. C. Jacobson and $\mathrm{K}$. Hosoi, 'The morphologie changes in animal tissues due to heating by an ultrahigh frequency oscillator', Arch. path., 11 (1931), 751-758.

${ }^{10}$ H. R. Hosmer, 'Heating effects observed in a high frequency static field', Science, 68 (1928), 325327, especially p. 327; and Bierman and Schwarzchild (footnote 8), 6.

${ }^{11}$ R. V. Christie, 'Conduction of high frequency currents through the living cell', J. exp. med., 48 (1928), 235.

${ }^{12}$ R. V. Christie and A. L. Loomis, 'Relationship of frequency to physiological effects of ultra-high frequency currents', J. exp. med., 49 (1929), 321.

${ }^{13}$ W. M. Baldwin and W. C. Nelson, "The histologic effects produced in albino rats by high frequency currents', Proc. Soc. Exper. Biol. and Med., 26 (1929), 588-590; and Baldwin and M. Dondale, 'High frequency currents in rats', Ibid, 27 (1929), 65-66.
} 
Paramecia were discovered to be due to heat. ${ }^{14}$ And most importantly, a significant number of papers confirmed the therapeutic effects of ultra-high frequency induced fevers in attenuating disease. ${ }^{15}$ By 1931 Schereschewsky began to withdraw from his earlier position that the effects he observed were nonthermal, and by 1933 he agreed that the only effects were thermal in nature. ${ }^{16}$

The weight of this evidence and the reversal of position of a major figure such as Schereschewsky put a great deal of pressure on the few researchers who argued for nonthermal effects. Nonetheless, some did continue to hold this position. G. M. McKinley, a biologist at the zoological laboratories of the University of Pittsburgh, found in 1930 what he believed to be lethal, nonthermal effects on wasps, and in another publication of the same year he reported nonthermal effects on the growth of seedlings and the nervous reactions of frogs. His conclusion in the latter paper was that 'it is evident here that high frequency and heat are by no means synonymous, and that although the electrostatic field carries with it potentialities for internal heat as a by-product, there is at the same time another and little understood reaction ... ${ }^{17}$ Similarly, W. T. Szymanowski and R. A. Hicks, of the Institute for Pathology at the Western Pennsylvania Hospital in Pittsburg, reported in 1930 that certain frequencies of ultra-short wave radiation had a nonthermal, attenuating effect on diphtheria toxin. This finding was confirmed in a 1932 paper. ${ }^{18}$ But Szymanowski and Hicks did not give unqualified support for nonthermal effects. A later report in 1932 ended with the curious conclusion that

the previously reported attenuation of diphtheria toxin by the direct action of the high frequency current without an action through heat may constitute the only basis of a belief that the electric field is directly concerned in any therapeutic action observed. The meager character, however, of the action on diphtheria toxin and the delicacy of the conditions under which it may be detected in any degree make it a phenomenon of relative insignificance in the interpretation of clinical or other studies of high frequency currents. ${ }^{19}$

This remarkable understatement of their findings led later researchers to report erroneously that Szymanowski and Hicks, like Schereschewsky, had in the final analysis rejected nonthermal effects.

\footnotetext{
${ }^{14} \mathrm{H}$. Kahler, H. W. Chalkley and Carl Voegtlin, 'The nature of the effect of a high-frequency electric field upon paramoecium', Pub. health rep., 44 (1929), 339-347.

${ }^{15}$ F. Bishoff, H. Ullmann, E. Hill and M. L. Long, 'Studies in hyperthermia induced by the high frequency electric current', J. biol.chem., 85 (1930), 675-686; C. M. Carpenter and R. A. Boak, 'The effect of heat produced by an ultra-high frequency oscillator on experimental syphilis in rabbits', Am.j. syph., 14 (1930), 346-365; Carpenter and A. B. Page, 'Production of fever in man by short radio waves', Science, 71 (1930), 450-452; B. Mortimer, 'Experimental hyperthermia induced by the high frequency current', Radiology, 16 (1931), 205 219; A. Knudson and P. J. Achaible, 'Physiologic and biochemical changes resulting from exposure to an ultrahigh frequency field', Arch. path., 11 (1931), 723-743; Jacobsen and Hosoi (footnote 9); E. E. Ecker and M. O'Neil, 'Effect of hyperpyrexia induced by an ultra-high frequency current on B. typhosus agglutinin and complement', Am.j. pub. health, 22 (1932), 1050-1054.

${ }^{16} \mathrm{~J}$. W. Schereschewsky, 'Biological effects of very high frequency electro-magnetic radiation', Radiology, 20 (1933), 246-253; and 'Heating effect of very high frequency condenser fields on organic fluids and tissues', Pub. health rep., 48 (1933), 844-858.

${ }^{17}$ G. M. McKinley and D. R. Charles, 'Certain biological effects of high frequency fields', Srience, 71 (1930), 490; and (4. M. McKinley, 'Some biological effects of high frequency electrostatic fields', Proc. Penn. Acad. Sci., (1930), 46.

${ }^{18}$ R. Mellon, W. T. Szymanowski and R. A. Hicks, 'An effect of short electric waves on diphtheria toxin independent of the heat factor', Science, 72 (1930), 74-75; and Szymanowski and Hicks, 'The biologic action of ultra-high frequency currents', $J$. infect. dis., 50 (1932), 1-25.

${ }^{19}$ Szymanowski and Hicks, 'Further studies on the biologic action of ultra-high frequency currents', J. infect. dis., 50 (1932), 471.
} 
It was not only contradictory scientific information that sparked debate over thermal versus nonthermal effects. The specific effects that short-wave radiation were said to have on certain medical problems had led some investigators, such as Schliephake and his followers, to use it in a number of complaints of local pathology. However, researchers felt that the extravagant claims made for the nonthermal thera peutic effects of short-wave radiation were leading people to seek miracle cures. Since they felt that short-wave treatments had a legitimate therapeutic value in raising temperatures, physical therapists, especially, were concerned to dismiss claims of nonthermal effects in order to gain acceptance for the more limited but important claims for its use in heat therapy. A significant body of literature took this for its major purpose. William Bierman, of the Department of Physical Therapy, Beth Israel Hospital in New York, working in conjunction with the physicist, Myron Schwarzchild, strongly supported the limited use of short-wave diathermy, or 'radiothermy' as they called it. ${ }^{20}$ Members of the Department of Physical Therapy at Northwestern University Medical School developed what they termed an 'inductotherm' as well as writing on the general usefulness of diathermy. ${ }^{21} \mathrm{By} 1933, \mathrm{~A}$. Halphen and J. Auclair could confidently reflect on this and other work and report that nonthermal or 'specific' effects were not truly present. ${ }^{22}$ As a fitting conclusion to this work, E. L. Chaffee, Gordon McKay Professor of Physics and Communication Engineering at Harvard University, went on to explain in 1935 why physical considerations dictated that only heating occurred in short-wave treatments. ${ }^{23}$

Concern over the claims of cures from specific, nonthermal effects of short-wave treatments reached the American Medical Association in 1935. In a preliminary report written by Frank $H$. Krusen and published in the 16 April 1935 issue of the Journal of the American Medical Association, the Council on Physical Therapy discussed the problem of the 'enormous sale to the medical profession of a new type of high frequency apparatus'. ${ }^{24}$ These sales were promoted by the use of the claims of Schliephake and others about the value of 'specific' treatments. Such promotion presented a definite threat, first because it was based on misleading and erroneous claims, and second, because it led physicians to believe in the simplicity, ease, and safety of the application of such currents. Krusen noted that 'the apparatus is not entirely safe or simple to operate', and went on to conclude that 'extensive employment of these machines at the present time can lead only to unsatisfactory results and may cause condemnation of a method of treatment that might otherwise be found serviceable'. ${ }^{25}$ The final report of the Council on Physical Therapy,

\footnotetext{
${ }^{20}$ W. Bierman and M. Schwarzschild, 'General hyperthermia with heat localization by radiothermy', Proc. Soc. Exper. Biol. and Med., 29 (1932), 439441.

${ }^{21} \mathrm{~S}$. L. Osborne and D. E. Markson, 'Electropyrexia: a resume of therapeutic application and technics', Annals internal med., 7 (1934), 1391; J. R. Merriman. H. J. Holmquest and S. L. Osborne, 'A new method of producing heat in tissue: the inductotherm', Am. j. med. science, 187 (1934), 677-683.

${ }^{22}$ A. Halphen and J. Auclair, 'A new form of "Arsonvalization"- the short waves', Arch. phys. therapy, 14 (1933), 69-71. Similar views were put forth at two major conferences later in the decade: Third annual fever conference, proceedings (1934, New York); and Fourth annual fever conference, proceedings (1934, New York).

${ }^{23}$ E. L. Chaffee, 'Physics of high frequency currents as used in medicine: diathermy, radiothermy and electric knife', N. Eng. j. med., 213 (1935), 505-508. For similar reports by foreign researchers, see 'Discussion on short-wave diathermy', Proc. Royal Soc. Med., 28 (1935), 301-318,30 (1937), 21 1-220; and H. J. Taylor, 'The effect of the high-frequency radio field on experimental rat tumours with special reference to the so-called "Specific Effect", Brit.j. radio., 8 (1935), 718-721.

${ }^{24}$ F. H. Krusen, 'Short wave diathermy. Preliminary report', J. Am. Med. Assoc., 104 (1935), 1237.

${ }^{25}$ Ibid., 1239.
} 
authored by B. Mortimer and S. L. Osborne and published on 20 April 1935 in the same journal, reaffirmed the commitment of the medical community to a belief in only thermal effects. Undertaken 'in order that the medical procession may not be misled into believing that this form of therapy has unusual healing powers and other clinical advantages', the report's conclusion was, although unacknowledged, word for word the same as those of Christie and Loomis in 1929: "the burden of proof still lies on those who claim any biologic action of these currents other than heat production'. ${ }^{26}$

This view of the biological effect of short-wave radiation dominated the research of the immediate prewar years. By 1937, when the First International Conference on Fever Therapy was held at the College of Physicians and Surgeons at Columbia University, the overwhelming majority of the papers presented on short-wave therapy agreed that it was useful to raise systemic temperatures and for no other purposes. ${ }^{27}$ Similarly, at the First International Congress on Short Waves held in Vienna that same year, it was generally agreed that specific and selective heating effects had not yet been proven to exist. ${ }^{28}$ Although several people still held to the position that specific effects were present, by the second half of the $1930 \mathrm{~s}$ most researchers seemed satisfied that the only proven effects or therapeutic value in short-wave treatments lay in its general thermal effects. The only disagreement that was investigated revolved around the question whether the heating could be 'selective' or was of necessity general. ${ }^{29}$

To summarize, it is clear from the literature that the scientific research that forms the immediate background to the investigation of the biological effects of microwave radiation was conducted primarily at medical schools by medical researchers who were interested in therapeutic application. The majority of these researchers assumed that the only demonstrated effects of that portion of the electromagnetic spectrum under investigation were thermal in nature. By the late 1930s, no established researchers maintained unqualified support for nonthermal effects. Moreover, as researchers looked ahead to the future, prospects for further developments appeared bright. The economic return on short-wave machines as well as short-wave radios caused the technical community to continue work looking for shorter wavelengths and higher powers. In 1937 the triode was developed by Lee de Forest and the magnetron tube improved at Bell Telephone Laboratories. A breakthrough was engineered by researchers at Stanford when in March of 1939 they developed the Klystron tube. This allowed them to generate wavelengths as short as $10-40 \mathrm{~cm}$ at outputs of several hundred watts. The age of microwave radiation had arrived.

${ }^{26}$ B. Mortimer and S. L. Osborne, 'Tissue heating by short wave diathermy', J. Am. Med. Assoc., 103 (1935), 1413, 1418.

${ }^{27}$ See footnote 9 above.

${ }^{28}$ Internationaler Kongress für Kurzwellen (1937, Vienna).

${ }^{29}$ For papers arguing for specific effects, see Albert Bachem, 'Selective heat production by ultrashort (Hertzian) waves', Arch. phys. therapy, 16 (1935), 645-650; J. S. Coulter and S. L. Osborne, 'Short wave diathermy: a comparative study in pelvic heating', Arch. phys. therapy, 17 (1936), 135-139; and Coulter and H. A. Carter, 'Heating of human tissues by short wave diathermy', J. Am. Med. Assoc., 106 (1936), 2063-2066. Discussions dealing with the selective versus general controversy include W. Holzer and $\mathbf{E}$. Weissenberg, Foundations of short wave therapy (1935, London); G. M. McKinley, 'Short electric wave radiation in biology', in B. M. Duggar (ed.), Biological effects of radiation (1936, New York), vol. 1, 541558; and P. Liebesny, 'Athermic short-wave therapy', Arch. phys. therapy, 19 (1938), 73. 
Medical researchers in the forefront of short-wave therapy followed these developments closely. Among those interested were persons at the Mayo Clinic, including F. H. Krusen, who had written the first 1935 report for the Council on Physical Therapy. The Mayo group was in correspondence with the several engineering groups and anxiously awaited a chance to use microwaves in diathermy. By early 1940, however, all Klystron and magnetron tubes became unavailable for medical use. ${ }^{30}$ In September of 1940 , unknown to the medical people, Sir Henry Tizard head of the British Technical Mission to the United States, brought to the States the multicavity magnetron tube. The development of this tube made the generation of very high-power microwave radiation possible, and with it the possibility of developing what came to be called radar. All microwave tubes were put to use in the escalating preparations for war. Medical research on microwave diathermy was postponed until the cessation of hostilities.

\section{The war years and after, 1940-1953; military interest in harmful effects}

The impact of the war years on research on the biological effects of electromagnetic radiation was rapid in coming'and without a doubt important. Because radar was crucial to the war effort--it increased the capabilities of air warfare and was indispensable in keeping the sea lanes open-research on radar technology received the same high priority as research on the atomic bomb. ${ }^{31}$ At the same time, reports of biological effects experienced by personnel exposed to radar-warming, baldness and temporary sterility being the most frequently mentioned-prompted the military to investigate the problem of possible hazards. Thus, within a matter of a few years the research on the therapeutic benefits of diathermy treatment gave way to personnel and clinical studies searching for radar-induced hazards and the medical school context was replaced by the military laboratory. The pre-war interest in diathermy would not return until the late $1940 \mathrm{~s}$ and then, as will be discussed below, only for a few years.

The investigations undertaken by the military early in the war reflected the mixed background of the new microwave technology. Its higher energy levels and shorter wavelengths placed it in a category midway between the benefits of diathermy and the known hazards of ionizing radiation. But where between the two did it fall? To answer this question the military turned in 1942 to the Navy Bureau of Medicine and Surgery for technical advice.

The advice it received, in a report issued by $\mathrm{J}$. B. Trevor, a radio engineer, concluded that only soft gamma or Grenz rays given off as a by-product of the magnetron tubes could cause harmful effects, and simple shielding could prevent any such emanations. The microwave beam itself was not thought to be harmful. The thinking that lay behind this and other advice given to military commanders was made clear in another report on the same subject issued by Division 14 of the National Defense Research Council. This report indicates that the technical advisors clearly viewed radar as little more than high-powered diathermy units. As the NDRC report noted, 'the power which can be dissipated in a subject exposed to

\footnotetext{
${ }^{30}$ F. H. Krusen, J. F. Herrick, K. G. Wakim and Ursula Leden, 'Microkymatotherapy: preliminary report of experimental studies of the heating effect of microwaves (radar) in living tissues', Proc. Mayo Clinic, 22 (1947), 210.

${ }^{31}$ See Henry E. Guerlac, 'Radar in World War II' (unpublished manuscript, 2 vols., for Office of Scientific Research and Development, circa 1948).
} 
microwaves from the radar systems of highest power under the worst possible conditions (a paraboloid stationary [antenna] with subject directly in front of it and absorbing all the incident energy) is of the same order of magnitude as that used in high frequency therapy'. ${ }^{32}$

That these early technical reports did not fully settle the problem of potential radar hazards is indicated by the fact that they were soon followed by personnel surveys and laboratory tests that sought further clarification of the situation. The first of the personnel surveys was undertaken by two pharmacist's mates and drawn together in a report published by Lieutenant Commander L. Eugene Daily in 1943. Based on a twelve-month clinical study of forty-five civilian personnel involved with experimental radar work at the Naval Research Laboratory, Daily's report assured its readers that radar presented no health hazards. Four tables summarized the results of blood counts, physical examinations, and inquiries into pregnancies. The blood counts were crude, the reports of physical examinations sketchy, and the table on marital status and number of children uninformative. Headaches and a 'flushed feeling' were reported, but felt to be quite unimportant. Otherwise, Daily reported, the physical and blood examinations were normal, and no sterility or balding could be attributed to exposure to radar. In sum, 'there has been no clinical evidence of damage to these personnel'. Since, to quote Daily, 'the radio-frequency energy of radar is not different from that of other high-frequency radio or diathermy units of an equivalent average power', these results were not unexpected. The 'medical' thinking that underlay the NDRC report and earlier diathermy research was still clearly in evidence. ${ }^{33}$

The Air Force, then still part of the Army, also took an interest in confirming that radar was not harmful to personnel. Again, the major impetus behind these studies was the morale problem. As the first Army Air Force report remarked, 'although field investigations cast doubt that radar waves were a dangerous form of electromagnetic radiation, rumors persisted that sterilization or alopecia [baldness] might result from such exposure'. ${ }^{34}$ As a result, the Director of Communications at the Headquarters of the Army Air Force in charge of radar units commissioned a study by the Aero Medical Laboratory of the Air Technical Service Command, Engineering Division, to allay such fears. This study exposed thirteen male guinea pigs to radar for three hours daily for fifty-one to fifty-three days. The guinea pigs were weighed, their temperatures taken each day, and at the conclusion of the study bred with females and sacrificed for histological examination. The conclusion that followed was that 'no effects were noted on the appea rance, growth, body temperature or reproduction. Histological examination of the tissues failed to reveal any changes' ${ }^{35}$

A second study, commissioned by the Army Air Force and published in the Air surgeon's bulletin in December 1945, concentrated on hemotologic examinations of 124 personnel who had been exposed to radar. The results reported indicated that erythrocyte counts were lower in exposed personnel than the commonly accepted

\footnotetext{
${ }^{32}$ Quoted in B. I. Lidman and C. Cohn, 'Effect of radar emanations on the hematopoietic system', Air Surgeon's bull., 2 (1945), 448.

${ }^{33}$ L. E. Daily, 'A clinical study of the results of exposure of laboratory personnel to radar and high frequency radio', U.S. naval medical bull., 41 (1943), 1052-1056.

${ }^{34}$ R. H. Follis, Jr., 'Studies on the biological effect of high frequency radiowaves (radar)', $A m . j$. physiol., 147 (1946), 281. Follis's study was the first of two undertaken by the Air Force, but the second to be published.

${ }^{35}$ Ibid., 282-283.
} 
level, but they were felt to be 'within the same range as that of the controls'. The reticulocyte counts were 'significantly higher in the exposed subjects than in the controls', but these too were thought to be 'within the normally accepted range'. The authors therefore concluded, perhaps not for fully justifiable reasons, that 'no evidence was discovered which might indicate stimulation or depression of the erythropoietic and leukopoietic systems of personnel exposed to emanations from standard radar sets over prolonged periods'. ${ }^{36}$

Thus, by the end of the war, the published reports from the military indicated that no harm would come to its technical personnel involved with radar operations. The few confirmed effects- headaches and flushing-were certainly not very serious in light of the importance of radar to the war effort. Comparisons to medical diathermy confirmed the results of the three clinical and laboratory studies, for it was not expected that something akin to a therapeutic process could cause harm. Moreover, the problem seemed to be more one of morale than a true health problem, and to be based on little scientific support.

\section{Return to therapeutic interest}

With the war effort over and the problem of the harmful effects of radar solved, or so it was thought, research on biological effects returned to the state it had been in immediately before the war-looking expectantly to microwave technology for new techniques and methods of treatment. The lead in this renewed research effort came quickly to focus on a group of persons at the Mayo Clinic, many of whom had been active in the field of diathermy research before the war and radar research during the war. By June 1946, the Mayo group, using the recently made-available multicavity magnetron tubes produced by the Raytheon Company, began its medical experiments on 'microkymatotherapy' or, as others soon called it, 'microwave diathermy' ${ }^{37}$ The actual clinical work was undertaken by Ursula Leden, with the assistance of Khalil Wakim and J. F. Herrick. Herrick had worked with the U.S. Signal Corps during the war on their technical studies of radar and was well acquainted with the work done at the Radiation Laboratory at MIT, where most of the research and development effort had been undertaken. Herrick's excitement over microwave diathermy was partly the result of a discovery made during the war but kept secret - different parts of the atmosphere absorbed microwaves at different rates. This discovery suggested to Herrick that different tissues of the body might absorb microwave radiation at different rates, thus yielding true selective heating. This hope was borne out by the first experiments. As Krusen noted in his 1947 summary of the early work, 'our studies indicate a desirable relationship between cutaneous and internal temperatures which permits adequate internal heating without undue heating of the cutaneous surface. It would seem that heating by microwaves offers promise of considerable usefulness in the practice of physical medicine'. ${ }^{38}$

The commercial production after the war of the Raytheon microtherm, which generated $12.25 \mathrm{~cm}$. microwaves at powers up to 125 watts, permitted other researchers to explore the merits of microwave diathermy. Their findings largely confirmed those of the Mayo group. In a cautious endorsement of microwave

\footnotetext{
${ }^{36}$ Lidman and Cohn (footnote 32), 449.

${ }^{37}$ Krusen et alii. (footnote 30), 212.

${ }^{38}$ Ibid., 214, 224.
} 
diathermy in 1948 by the AMA's Council of Physical Medicine, S. L. Osborne and J. N. Frederick concluded that such therapy could induce localized heating with little discomfort and with no evidence of damage to the eyes or contiguous tissues. ${ }^{39}$ Researchers at the Department of Physical Medicine at the University of Pennsylvania reached basically the same conclusion regarding the production of localized sub-cutaneous heating. ${ }^{40}$ In the years following, many articles appeared confirming these early findings. ${ }^{41}$ Microwave diathermy, as a therapeutic technique, was rapidly coming of age.

\section{The discovery of medical hazards}

Just as the effort was getting underway in 1948 to study the possible uses of the new microwave diathermy, two groups of researchers, at the Mayo Clinic and the University of Iowa, reported results that would have a drastic impact on the future of the field. Both groups discovered, apparently independently of each other's work, hazardous effects that stemmed from microwave exposure. Louis Daily, of the University of Minnesota and an affiliate of the Mayo Clinic, briefly described cataracts that appeared in dogs exposed to direct microwave radiation, ${ }^{42}$ at the same time that researchers at the University of Iowa, working under H. M. Hines, were publishing two longer articles describing lenticular opacities in rabbits and dogs and testicular degeneration in rats. ${ }^{43}$ Reaction to this work was slow in coming. Serious funding for hazards research would not become available on any major scale for another five years. But in the long run, the discoveries of 1948 set in motion once again a shift in research patterns from medical to military camps and from a focus on beneficial effects to a search for hazards.

At the time these reports were published, the researchers at the University of Iowa felt that they had been 'scooped' by the Mayo group after having reported their findings in an open meeting. ${ }^{44}$ However, there is another plausible explanation of the Mayo group's interest in the possible harmful effects of microwave diathermy. Cataracts had long been known to result from heat, as evidenced by their unusual occurrence in glassblowers and chainmakers. They had also been produced experimentally by infrared radiation. Daily, as an ophthalmologist, knew this and, since he had been using short-wave diathermy to treat diseases of the eye and wished

${ }^{39}$ S. L. Osborne and J. N. Frederick, 'Microwave radiations: heating of human and animal tissues by means of high frequency current with wavelength of 12 centimeters (microtherm)', J.Am. Med. Assoc, 137 (1948), 136-140.

${ }^{40} \mathrm{~S}$. M. Horvath, R. N. Miller and B. K. Hutt, 'Heating of human tissues by micro wave radiation', Am. j. med. sciences, 216 (1948), 430-436.

${ }^{41}$ See, for example, J. W. Gersten, K. G. Wakim, J. F. Herrick and F. H. Krusen, The effects of microwave diathermy on the peripheral circulation and on tissue temperature in man', Arch. phys. med., 30 (1949), 7-25; J. W. Rae, J. F. Herrick, K. G. Wakim, and F. H. Krusen, 'A comparative study of the temperatures produced by microwave and short wave diathermy', Arch. phys. med., 30 (1949), 199-211; K. G. Wakim, J. F. Herrick, G. M. Martin and F. H. Krusen, 'Therapeutic possibilities of microwaves', $J$. Am. Med. Assoc., 139 (1949), 989-993; W. H. Oldendorf, 'Focal neurological lesions produced by microwave irradiation', Proc. Soc. Exper. Biol. and Med., 72 (1949), 432-434.

${ }^{42}$ L. Daily, Jr., K. G. Wakim, J. F. Herrick and E. M. Parkhill, 'Effects of microwave diathermy on the eye, abstracted', Am.j.physiol., 155 (1948), 432.

${ }^{43}$ A. Richardson, T. Duane and H. Hines, 'Experimental lenticular opacities producd by microwave irradiations', Arch. phys. med., 29 (1948), 765-769; and C. J. Imig, J. D. Thomson and H. M. Hines, 'Testicular degeneration as a result of microwave irradiation', Proc. Soc. Exper. Biol. and Med., 69 (1948), $382-386$.

44 'Biological effects of microwaves' (unpublished Navy Department Conference, held 29 April 1953, Naval Medical Research Institute, Bethesda, Maryland, 33); and private communication (Duane). 
to apply microwave diathermy similiarly, took a look at the possible effects of such radiation before putting it to use. In the process, he found that direct radiation of the eye at high intensities could produce cataracts. ${ }^{45}$

Impetus for the Iowa studies found its origin in a very different setting. The Iowa group was funded by Collins Radio Company at Cedar Rapids, Iowa, who in turn were subcontractors for the Air Force's Rand Corporation. ${ }^{46}$ The project that Collins Radio had undertaken for the Air Force was to explore the possibility of using microwaves to transmit power over long distances. (In 1949, an engineer from Collins Radio demonstrated to the public the feasibility of such transmission by setting up a device at the Iowa State Fair that could pop popcorn in a bag. ${ }^{47}$ ) The effect such a device could have on humans was of sufficient concern to researchers at Collins Radio to prompt them to seek the advice of the Department of Physiology at the nearby university. Thus whereas the Mayo group began their work within a medical context and by looking for benefits, the Iowa research stemmed from an engineering problem and was focused squarely on hazards.

Using the newly developed Raytheon microtherm, two groups of researchers at Iowa, working under the direction of $\mathrm{H}$. M. Hines, began the search for hazards sometime in 1947. Since it was a commonplace that microwaves generated heat in tissues, they proceeded on the assumption that physiological damage would most likely occur in avascular areas, where the blood could not as efficiently carry off excess heat. This made the eye an obvious choice for investigation. As one of the papers put it, 'it was thought that since the center of the eye is a relatively avascular area it might be less capable of heat dissipation than other more vascular areas'. ${ }^{48}$ Moreover, since heat was also known to cause testicular degeneration and since the testicles are also relatively avascular, the effects of microwave radiation on that area of the body was looked into as well. In the final in-house paper presented to Collins Radio, the researchers reported that in both areas 'definite evidence has been found that injury may occur at relatively low field intensity'. 49

The new-found evidence of injury gave a few of those who were aware of the findings cause for concern. Microwave radiation exposure was as yet unregulated. No standards existed to control the exposure of personnel to the possible dangers of microwave radiation. ${ }^{50}$ Lacking controls, researchers at Collins Radio warned in a report published in Electronics in 1949 that 'microwave radiation should be treated with the same respect as are other energetic radiations such as $X$-rays, $\alpha$-rays, and neutrons'. ${ }^{51}$ The fears expressed by these researchers were not directed to existing exposure levels. The radar units in operation were of relatively low power. But this situation would not last and therefore these same persons felt that it would be highly desirable in the light of these observations to set about establishing standards for the protection of personnel exposed to intense microwave radiation before anyone is

\footnotetext{
${ }^{45}$ Navy Department Conference, 1953 (ibid.), 33; and private communication (Daily).

${ }^{46}$ The Air Force set up a research and development branch in 1946, named 'RAND', and in 1948 endowed it as a semi-public corporation called 'The Rand Corporation'.

${ }^{47}$ Private communication (Randall).

${ }^{48}$ Richardson et alii (footnote 43 ), 765.

${ }^{49}$ W. W. Salisbury, John W. Clark and H. M. Hines, 'Physiological damage due to microwaves' (27 December 1948), unpublished Collins Engineering Report P-58, 1. The 'low field intensity' consisted of a 10-minute exposure at 3 watts $/ \mathrm{cm}^{2}$.

${ }^{50}$ For a discussion of the origin of microwave safety standards, see Steneck et alii (footnote 2).

${ }^{51}$ W. W. Salisbury, John W. Clark and H. M. Hines, 'Exposure to microwaves', Electronics, 22 (1949), 66.
} 
injured. We have here a most unusual opportunity to lock the barn door before, rather than after, the horse is stolen'. ${ }^{52}$ To achieve this end, more research was needed. Again, Collins-Radio spokesman, John W. Clark, pointed the way: 'The work which has been described is of a very preliminary nature. We have definitely established that it is possible to produce serious tissue damage with moderate amounts of microwave energy but have no idea of the threshold energy, if one exists, for these phenomena. Further work along these lines is urgently needed'. ${ }^{53}$

However, research on hazards did not proceed at an accelerated pace in the wake of these reports and warnings. Daily's work at the Mayo Clinic continued, ${ }^{54}$ as did a portion of the Iowa research that was picked up by the Office of Naval Research when the Rand Corporation ended its subcontract with Collins Radio in 1948. Two years later, ONR also began funding the work of Herman Schwan, a German-trained biophysicist who was hired by the Moore School of Engineering at the University of Pennsylvania. ${ }^{55}$ But the lack of a present danger kept such work at a bare minimum and as a result it had little impact on the medical community and the use of microwave diathermy. Thus, as late as 1952, an anonymous respondent for the Journal of the American Medical Association could confidently dismiss a question regarding the possible connection between microwaves and cataracts with a simple, straightforward answer: 'Radar waves are completely absorbed by the cornea and have not been reported to be a cause of cataracts. The Grotthus-Draper law requires that absorption of radiation must take place for a reaction to be produced. Thus, in the absence of penetration of the cornea, radar waves will not cause any change in the lens transparency'. ${ }^{56}$ Clearly the independent reports of 1948 connecting cataract formation to microwave exposure were not taken seriously by some in the research community. More evidence was needed before the search for cures was replaced by the search for hazards.

\section{Renewed concern, 1953-1957: worries of industry}

The chain of events that eventually precipitated widespread concern over possible hazardous effects of microwaves had their origin in mid-1952, a few months before the publication of the statement on cataracts published in the Journal of the

${ }^{52}$ John W. Clark, 'Effects of intense microwave radiation on living organisms', unpublished Rand Report P-122 (7 March 1950), 3; and 'Effects of intense microwave radiation on living organisms', Proc. Inst. Radio Engineers, 38 (1950), 1028-1032.

${ }^{53}$ John W. Clark ibid., 6.

${ }^{54}$ L. Daily, Jr., K. Wakim, J. Herrick, E. Parkhill and W. Benedict, 'The effects of microwave diathermy on the eye: an experimental study', Am.j. ophth., 33 (1950), 1241-1254; Daily, E. Zeller, Wakim, Herrick and Benedict, 'Influence of microwaves upon certain enzyme systems in the lens of the eye', Am.j. ophth., 34 (1951), 1301-1306; Daily, Wakim, Herrick, Parkhill and Benedict, 'The effects of microwave diathermy on the eye of the rabbit', Am.j. ophth., 35 (1952), 1001-1017.

${ }^{55}$ See 'The bird dogs, the evolution of the Office of Naval Research', Physics today, 14 (1961), 30-35; and John E. Pfeiffer, 'Th Office of Naval Research', Scientific American, 180 (1949), 11-15. ONR began funding the work of A. Richardson at this time. For an explanation of the termination of Rand Corp. funding, see Steneck et alii (footnote 2).

56 'Radar and cataracts', J. Am. Med. Assoc., (1952), 528. Examples of the continued search for medical application can be found in A. C. Boyle, H. F. Cook and T. J. Buchanan, The effects of microwaves. A preliminary investigation', The Brit. $j$. of physical med., (1950), 2-9; A. J. Murphey, W. D. Paul and H. M. Hines, 'A comparative study of the temperature changes produced by various termogenic agents', A rch. phys. med., 31 (1950), 151-156; G. Smith, 'Effect of diathermy currents on metal implants in the body wall', Brit. med.j., 1 (1950), 1466-1467; B. K. Hutt, J. Moore, P. C. Colonna and S. M. Horvath, 'The influence of microwave irradiation on bone temperature in dog and man', Am.j. physical med., 31 (1952), 422-428; and W. B. Clark, 'Microwave diathermy in ophthalmology: clinical evaluation', Trans. Amer. Acad. Ophth. and Otolaryn., 56 (1952), 600-607. 
American Medical Association. At this time, John T. McLaughlin, a physician and medical consultant at Hughes Aircraft Corporation in Culver City, California, had brought to his attention a case of Purpura hemorrhagica (internal bleeding) suffered by a young male employee who had required hospitalization. The hospital called McLaughlin to ask with what the young man had been irradiated, since his blood picture resembled that often seen in mild radiation cases. McLaughlin came to suspect that microwave radiation might have been the cause, and by early 1953 had turned up an estimated 75 to 100 cases of purpura at Hughes out of a total work force of about 6,000. Some cases showed extensive internal bleeding and needed hospitalization and transfusion. Investigating further, he found questionable cases of cataracts among employees of Hughes in addition to a 'universal complaint of headaches by personnel working in the vicinity of microwave radiation'. ${ }^{7}$

These discoveries prompted McLaughlin to seek other opinions on the possible hazards of microwave radiation. When he did, he found that others were as concerned as he was. Hines, at the University of Iowa, was still investigating the effects of microwave radiation and trying to discover whether heat alone or resonance was the cause of the effects. Robert Reed Newell, of the Stanford Medical School, agreed with McLaughlin that microwave radiation ought to be thoroughly investigated. The Air Force's Material Command, Paterson Field, had set Lt. Colonel John E. Boysen to work investigating the possible human health hazards of the new high-powered radar being developed there. Boysen's investigations into the effects of whole body irradiation of rabbits eventually convinced the Command that microwave radiation ought to be completely reviewed. Officers at the Aero-Medical Laboratory, Wright Field, Ohio, of the Army Air Force, were talking about beginning a research project in the field and had assigned Captain $\mathbf{R}$. W. Ballard to look into it. Since no money was appropriated for the study, however, Captain Ballard spent his time accumulating bibliography on the subject. Three additional groups of researchers were worried about ionizing radiation that was given off from radar (cathode) tubes. In sum, McLaughlin found that he was not alone in his belief that more research on hazards was needed. ${ }^{58}$

McLaughlin was also not alone in his discovery of more evidence connecting microwaves to hazards. A 1952 report by Frederic G. Hirsch, an M.D. in the Department of Occupational Medicine at the Lovelace Clinic and Director of Medicine and Biomedical Research at the Sandia Laboratories, both in Albuquerque, New Mexico, and John T. Parker, an M.D. in the Department of Ophthalmology of the Lovelace Clinic, outlined in some detail the clinical study of a 32-year-old technician who had developed cataracts after an extended period operating a microwave genera tor. Since the usual etiologies were missing, Hirsch and Parker felt that microwave exposure might have been the cause of the cataracts. The case was a complicated one, however. Estimating the level of radiation to which the technician had been exposed was very difficult. The individual often spent time sitting with his head near a microwave antenna and sometimes looked directly into it. As a result, when it came to conclusions the two researchers avoided categorically stating that the circumstantial evidence presented showed a direct cause and effect

\footnotetext{
${ }^{57}$ Navy Department Conference, 1953 (footnote 44), 5-8.

${ }^{58}$ Unpublished report, John T. McLaughlin, 1952-53 (supplied to us by the author), 15-19. Boysen's study was later published as J. E. Boysen, 'Hyperthermic and Pathologic Effects of electromagnetic radiation (350 MC)', Am. med. assoc, arch industrial hyg. and occup. med., 7 (1953), 516-525.
} 
relationship between microwave exposure and ocular pathology. There was no scientific proof. But they were curious and worried:

It will be well therefore to use this case as a means of recalling the attention of ophthalmologists, industrial physicians, and microwave operators to the potentialitis of microwave radiations in order that the use of this form of energy will be accompanied by appropriate respect and precaution. It is also important to realize that much remains to be learned about the various factors which control the absorption of microwave energy by tissue systems in a "near field' situation, to the end that further research may be stimulated. ${ }^{59}$

In addition to the Hirsch and Parker study, McLaughlin collected orally other pieces of information which in toto produced an alarming picture. One of his contacts reported two cases of leukemia among 600 radar operators and radiation illness from the soft $X$-ray radiation of unshielded cathode tubes. He also was informed that among one group of five men doing research on microwave radiation, two had died of brain tumors within a year and one had suffered a severe heart condition. Whether any of these physiological effects were due to microwave radiation, McLaughlin did not know, but he was suspicious. ${ }^{60} \mathrm{Mr}$. Tuttle, Hughes's Director of Industrial Relations, grew worried as well and authorized McLaughlin to prepare a report on his finding. ${ }^{61}$

At about the same time, the military was preparing its own preliminary assessment of the microwave problem in response to an inquiry from the Lockheed Aircraft Corporation, which was working with and installing radar in aircraft, and addressed to the Electronics Division of the Air Force's Bureau of Aeronautics. Commander Sidney I. Brody, Medical Liaison Officer from the Navy's Bureau of Medicine and Surgery to the Bureau of Aeronautics was assigned the task of assessing the problem. The Bureau of Medicine and Surgery was taken by surprise; the problem was new to them but, upon reviewing the literature, they felt that health hazards might result from exposure to radar systems. Brody prepared a report in which he outlined precautions for technical personnel, air crewmen, and pilots who might be exposed to radar. He was concerned with three-centimeter and tencentimeter wavelengths, since these were the ' $S$ ' and ' $X$ ' bands used in the new highpowered radar systems. ${ }^{62}$

\section{The military response to industrial concern}

The military's own internal questioning, which was undoubtedly spurred on by the urgent queries from industry and the fact that McLaughlin's report received very widespread circulation, brought them, beginning in early 1953, into the business of discussing, planning, and funding research on the biological effects of microwave radiation. As such, 1953 marks a watershed for this area of scientific research, since it

${ }^{59}$ F. G. Hirsch and J. T. Parker, 'Bilateral lenticular opacities occurring in a technician operating a microwave generator', Am. med.assoc. arch. ind. hyg. and occup. med., 6 (1952), 512-517. The output of the experimental generator in question varied. Still, Hirsch and Parker did try to estimate the average daily exposure, coming up with a figure of $0.5 \mathrm{watt} / \mathrm{cm}^{2} / \mathrm{day} \pm 15 \%$, and 12 watts $/ \mathrm{cm}^{2}$ on those days of most intense exposure.

${ }^{60}$ MeLaughlin (footnote 58), $5-6$.

${ }^{61}$ Navy Department Conference, 1953 (footnote 44), 16.

${ }^{62}$ Brody's report was later read at the twenty-fourth annual meeting of the Aero Medical Association in Los Angles, 11-13 May 1953, and then published as S. I. Brody, "The operational hazard of microwave radiation', J. aviation med., 24 (1953), 328-333. 
is in this year that the active involvement of the military begins and the interest of the medical community in therapeutic application starts to lessen. Two events within the military set the wheels in motion. On 28 April 1953 the Air Research and Development Command (ARDC) directed the Cambridge Research Center (a part of ARDC) to investigate the biological aspects of microwave radiation. One day later, on 29 April, the Navy convened a conference at the Naval Medical Research Institute at Bethesda, Maryland, for precisely the same purpose. ${ }^{63}$ The two separate events would soon bring a very different style of research to the microwave area.

Entry of a new funding agency-the military-into the biological effects area was not easily accomplished. (1) No mechanisms existed to direct funds to this area of research, nor was it evident how such mechanisms ought to be developed. Going through some branches of the military had the danger of tying research too closely to operations (and hence to applied research), going through others posed the problem of keeping the basic research in contact with operational developments (that is, abreast of the capacities of the new radar systems) and operations in contact with the results of basic research. ${ }^{64}$ (2) No clear research path was evident that needed to be followed. All present at the Navy Conference, for example, agreed that more work was needed, but they did not agree on what that work should be. Dosimetry, animal studies of purpura, surveys of personnel exposed to microwave radiation, laboratory studies (physical, biological, and clinical), hematological studies, studies on protective clothing, field studies, engineering studies, and medical studies were all suggested. ${ }^{65}$ (3) Finally, since any action taken by the military to pursue research on biological effects carried with it the clear implication that such effects were suspected, the planning of this research had to be undertaken with some cautionthe two worries at the Navy Conference were morale and press coverage -ven though there was also need for haste. ${ }^{66}$ In brief, at every turn there were competing factors that had to be sorted out before a plan of action could be established.

As a plan of action did emerge, first at the Navy Conference and then during the intervening years, it is clear that it came to be dominated by one overriding factorthe need to discover at what level exposure to microwave radiation presented a threat to health. This problem was of paramount importance to those who would more and more come to control the plan of action and as such it filtered down in very significant ways to the level of basic research. Many of the same basic techniques employed during the early years of diathermy research would still be used, but the motivation for such research now changed from 'can any beneficial effects be seen' to 'has any damage been caused?'.

The shift to hazards studies is evident in the medical research-the one active area of investigation at the time the military reentered the field —of the early $1950 \mathrm{~s}$. In 1952, Alfred Richardson of the University of Indiana (he had first worked in the University of Iowa group under Rand Corporation sponsorship but was funded at Indiana by ONR), did a study to determine whether temperature increases were directly responsible for the formation of cataracts or whether the temperature changes caused a disturbance in the metabolism of the lens, which in turn caused the

\footnotetext{
${ }^{63}$ Navy Department Conference, 1953 (footnote 44). For a discussion of prior actions taken by the Air Force, see p. 16 of the Conference report.

${ }^{64}$ Ibid.. $133-150$.

${ }^{65}$ Ibid., 116-133.

${ }^{66}$ Ibid., $30,78,83$.
} 
cataracts. ${ }^{67}$ Hines, at the University of Iowa, continued his work, seeking to discover the mechanism of the effects of microwaves, although his work was no longer funded.$^{68}$ G. N. Austin and S. M. Horvath found that convulsions in rats could be induced by elevating the brain temperature above that of the body by microwave heating, but added that specific brain temperature 'probably acts as a trigger mechanism for a more complex reaction' ${ }^{69} \mathrm{E}$. Adler and A. Magora found that the beneficial effect of microwave diathermy on rheumatoid arthritis was probably not due to heat alone, but to the condition of 'nonspecific stress of the pituitary-adrenal cortex system' that it induced, which caused a decrease in eosinophiles and a corresponding secretion of oxycortico-steroids, which helped reduce the pain. ${ }^{70}$ Finally, as a natural culmination to this work, when at the instigation of Krusen the Mayo Clinic sponsored a symposium on the 'Physiologic and pathologic effects of microwaves', held on 23 and 24 September 1955, not one paper dealt with the benefits of mic rowave diathermy. The only strictly medical study, by Daily $e t a l$. of the Mayo Clinic, was a reiteration of earlier studies by the group on microwaves and cataracts. ${ }^{71}$ As one final indication of the shift in focus from therapy to hazards, it is interesting to note that the symposium was published in the I.R.E. Transactions on Medical Electronics, an engineering journal. ${ }^{72}$

Industrial preoccupation with hazards is also apparent in the events of the early 1950s. At a meeting held at the General Electric Research Center in Schenectady, N.Y., on 1 June 1954 to deal with 'Microwave radiation: hazards and safety measures', G.E. scientists concluded that test data in the published literature on animal exposure to microwaves was meager, but that the eyes appeared to be the most sensitive organs; that there was no authoritative existing safety standard; that there were no generally recognized safety practices; that the research, development and testing of microwave equipment was increasing and spreading to new locations; and that the new equipment was of greater and more dangerous power levels. An earlier meeting convened by the Central Safety Committee of Bell Telephone Laboratories on 16 November 1953 , had reached similar conclusions. Both the G.E. and Bell Labs. meeting placed a great deal of weight on Hirsch and Parker's case study of the formation of cataracts in a radar worker (discussed in the previous section) at an estimated exposure level of 1 watt $/ \mathrm{cm}^{2}$ and went on to establish inhouse safety standards for their own workers. ${ }^{73}$ Although neither Bell Labs. nor G.E.

${ }^{67}$ Alfred W. Richardson, Donald H. Lomax, John Nichols and Harold D. Green. 'The role of energy, pupillary diameter, and alloxan diabetes in the production of ocular damage to microwave irradiations', Am. j. ophth., 35 (1952), 993-1000; Richardson concluded that both processes were at work.

${ }^{68}$ McLaughlin (footnote 58), 16.

${ }^{69}$ George N. Austin and S. M. Horvath, 'Production of convulsions in rats by high frequency electrical currents', Am.j. physical med., 33 (1954), 149.

${ }^{70}$ E. Adler and A. Magora, 'Experiments on the relation between short wave irradiation and the pituitary-cortical adrenal system', Am.j. phys. med., 33 (1955), 533.

${ }^{71}$ L. Daily, K. G. Wakim, J. F. Herrick, E. M. Parkhill and W. L. Benedict, 'The effects of microwave diathermy on the eye', I.R.E. trans. med. elect., ME-4 (1956), 25-26.

${ }^{72}$ Mayo Clinic and Mayo Foundation, 'Symposium on physiologic and pathologic effects of microwaves', I.R.E. trans. med. elect., ME-4 (1956).

${ }^{73}$ For summaries of the Bell Labs. and G. E. meetings, see W. W. Mumford, 'Some technical aspects of microwave radiation hazards', Proceedings of I.R.E., 49 (1961), 432; B. L. Vosburgh, 'Problems which are challenging investigators in industry', I.R.E. trans. med. elect., ME-4 (1956), 5-7; and H. Meahl, 'Protective measures for microwave radiation hazards 750 to $30,000 \mathrm{MC}$ ', I.R.E. trans. med. elect., ME-4 (1956), 16; and his 'Using microwaves safely, 750-30,000 MC', unpublished report, G.E. Laboratories, Technical Information Series No. R56GL56 (March 1956). Based on Hirsch and Parker's estimate of 0.1 watts $/ \mathrm{cm}^{2}$, G.E. assumed a safety factor of 100 and set their standard at $1 \mathrm{mw} / \mathrm{cm}^{2}$; Bell Labs. assumed a safety factor of 1000 and set their standard at $0 \cdot 1 \mathrm{mw} / \mathrm{cm}^{2}$. 
funded biological studies themselves, they were obviously worried about the health and safety of their workers in relation to microwave radiation.

The one industrial member that did sponsor research was the Lockheed Aircraft Corporation. Under the direction of Charles Barron, Lockheed began, in the spring of 1954, a series of 'comprehensive physical examinations-encompassing studies recommended by earlier medical investigators and within the operational limitations of an industrial medical department'. The studies were carried out with the objective of laying to rest the 'considerable apprehension and misunderstanding [that] has arisen among engineering and radar test personnel' concerning the effects of microwaves. ${ }^{74}$ Barron's group focused on 226 employees at Lockheed and a group of 88 people in a control group. Complete physical examinations were given; in addition, ocular and slit lamp studies, blood counts, platelet counts, urinalyses, and chest $\mathrm{X}$-rays were performed. Finally, each employee was questioned as to duration and manner of exposure and marital and fertility history.

The Lockheed study did uncover some differences between the exposed and control groups. 'Ophthalmological examinations revealed the presence of pathological conditions, other than accountable refractive errors, in twelve subjects among the radar group as contrasted to the one abnormal finding in the control group'. However, 'with the exception of a solitary unexplained punctate retinal hemorrhage in the radar group, the cause of all other abnormalities was established and could not be related to the thermal effects of radar'. ${ }^{75}$ The Lockheed study, as published, did not confirm the connection between microwaves and cataract formation.

A second finding of the Lockheed study was more difficult to account for. There was an 'apparent... significant decrease of polymorphonuclear cells below $\mathbf{5 5}$ percent in one quarter of the radar personnel which is disproportionately high when compared to the controls. Of further interest is the rather marked increase in monocytes (over 6 percent) and eosinophiles (over 4 percent) in the radar group. The significance of these changes cannot at this time be evaluated'. ${ }^{76}$ As a result, further work was undertaken in an effort to explain these changes. However, the follow-up studies did little to clarify the situation. No additional information was made available on blood cell counts and urinalyses, blood platelet studies, or electrophoretic serum protein analyses that were said to have been done. The 'apparent decrease in polymorphonuclear cells and increase in eosinophiles and monocytes' mentioned in the 1955 study were 'later found to be due to a variation of interpretation by a laboratory technician'. The conclusion was then reached that 'on the basis of these studies there appears to be no justification for public concern about the effects of greatly attenuated microwave energy in the environment'. ${ }^{77}$

With this study, industrial participation in the field of research on the biological effects of microwave radiation essentially came to an end. This fact, combined with the growing disinterest within the medical community in microwave diathermy, essentially left the field to depend overwhelmingly on its military sponsors for support and guidance. This support grew to major proportions during the latter half

\footnotetext{
${ }^{74}$ Charles I. Barron, A. A. Love and A. Baraff, 'Physical evaluation of personnel exposed to microwave emanation', J. aviation med., 26 (1955), 442.

${ }^{75}$ Ibid., 448.

${ }^{76}$ Ibid., 446.

${ }^{77}$ Barron and Baraff, 'Medical considerations of exposure to microwaves (radar)', J. Am. Med. Assoc., 168 (1958), 1194-1199. The archivists at Lockheed have to date been unable to locate the unpublished, inhouse reports that Barron apparently drew up.
} 
of the 1950 s in the form of a joint military program that has since become known as the 'Tri-Service Program'.

\section{The Tri-Service era: $1957-1960$}

Direct military involvement in research on the biological effects of microwave radiation at first took shape slowly after the 1953 Navy Conference and the ARDC directive of the same year. Two avenues were selected to initiate research, one through existing military research facilities, the other through subcontracts with university scientists. In both cases, however, the major emphasis, like that in medical and industrial circles during the same period, was aimed predominantly at the problem of hazards and the one issue regarding hazards that above all concerned the military - the exposure level at which injuries could be expected to appear. (By the mid-1950s, no one who fully understood the research that had been conducted doubted that injuries would occur if the dose levels were high enough.) This was the issue that brought the military into the business of funding basic research in this area, and it is the issue whose resolution (or at least assumed resolution) brought that funding near to an end by 1960 .

One of the earliest recipients of military funding, from ONR, was the Germantrained biophysicist Herman Schwan. Schwan had studied at the Max Planck Institute during the immediate pre-war years when debate over the thermalnonthermal issue was critical. His belief at that time and later was that microwaverelated effects had to be thermal in origin. This, he suggested, could be demonstrated either through the study of temperature changes in animals or, at a more basic level, by investigating 'the fundamental tissue properties responsible for the conversion of the "primary" radiation energy into heat... If one understands how such data may be interpreted in terms of the molecular components of tissues, it is possible to extrapolate this information to experimentally unexplored frequency ranges, thereby predicting more suitable techniques'. ${ }^{78}$

In sum, Schwan was suggesting - and this suggestion would have major impact on future research and policy decisions - that biophysical calculations should be used to guide the work of physiologists and clinicians. By means of calculations, he demonstrated that 'the efficiency of presently used microwave [research] apparatus... is unpredictable, from a practical point of view'. His calculations pointed to the need for 'more controlled critical studies on selected series of patients' before reaching 'final conclusions as to [the medical machine's] exact therapeutic indications'. ${ }^{79}$ Moreover, in a paper presented to the Mayo Symposium of 1955 , Schwan and $\mathrm{Li}$ did more than raise doubts about existing experimental techniques. Based on assumptions about the manner in which different frequencies of microwave radiation would be absorbed by different tissues of the body and where the absorbed energy would be transformed into heat, they went on to calculate the theoretical point at which hazards should be expected. ${ }^{80}$ Hereafter, when experimental

\footnotetext{
${ }^{78}$ Herman P. Schwan and George M. Piersol, 'The absorption of electromagnetic energy in body tissues. Part I; biophysical aspects', Am.j. phys. med., 33 (1954), 372.

${ }^{79}$ Ibid., 374, 401, 447 .

${ }^{80} \mathrm{H}$. P. Schwan and Kam Li, "The mechanism of absorption of ultrahigh frequency electromagnetic energy in tissues, as related to the problem of tolerance dosage', I.R.E. trans. med. elect., ME-4 (1956), 49. Schwan had earlier suggested in a brief memo to ONR that the initial estimate of a $0 \cdot 1 \mathrm{watt} / \mathrm{cm}^{2} \mathrm{safe}$ exposure level adopted at the 1953 Navy Conference was too high by a factor of 10 . The 1955 Mayo symposium paper confirmed this estimate and put Schwan on public record as supporting a $10 \mathrm{mw} / \mathrm{cm}^{2}$ standard. For Schwan's role in setting a microwave standard, see Steneck et alii (footnote 2).
} 
techniques were called into doubt, which they frequently were, researchers and policy makers had an impressive and highly respected theoretical framework to which they could, and often did, retreat.

Unlike Schwan's work, the in-house research sponsored by the military after 1953 remained experimentally based. The work undertaken at ARDC's Cambridge Research Center (at the Radiology Laboratory, Atomic Warfare Directorate) by D. B. Williams, et alii attempted to determine the exposure level at which cataract formation could be expected. Using a Raytheon microtherm, anesthetized rabibits were radiated to determine the exposure time and power density necessary for the production of ocular opacities. The results pointed to a base power-level of 0.12 watts $/ \mathrm{cm}^{2}$, below which no opacities were produced. The need for further research to determine whether there might be cumulative effects, however, was stressed. In lieu of such experiments, it was suggested that in the interim ... the present threshold [of 0.12 watts $/ \mathrm{cm}^{2}$ ] should be regarded as dangerous for human eyes until more definitive information is available' ${ }^{81}$ Since a similar threshold $\left(0 \cdot 1\right.$ watts $\left./ \mathrm{cm}^{2}\right)$ had emerged from the Hirsch-Parker study, the CRC study provided a rare piece of experimental verification of $\dot{a}$ prior result, although admittedly the two projects had only the study of cataract formation in common.

The other early experimental research undertaken at a military installation was. a study at the Naval Medical Research Institute by D. E. Goldman, who had chaired the $1953 \mathrm{Navy}$ conference, and T. S. Ely. The objective of this study was to determine the effect of ' $S$ '-band $(10 \cdot 4 \mathrm{~cm})$ pulsed radar on animals subjected to whole body radiation. Rise in body temperature was measured at different powers and the conclusion reached that a rise in body temperature of $1^{\circ} \mathrm{C}$ occurred in all animals at $25 \mathrm{mw} / \mathrm{cm}^{2}$. Although it was not suggested that this figure should be used to establish safety standards, nevertheless it was thought that 'this type of information may be of value from the hazard point of view' ${ }^{82}$ In the completed study, published in 1957 , testicular damage was reported to occur at levels as low as $5 \mathrm{mw} / \mathrm{cm}^{2}$, although this damage appeared to be noncumulative and entirely reversible. ${ }^{83}$

The studies of Ely, Goldman and Williams, together with the calculations advanced by Schwan, when combined with the existing data that had accumulated since World War II on hazards, left little doubt that there was cause for concern. In line with the actions taken by industry at about this same time, the military moved quickly to establish temporary 'standards' or guidelines for use in the field. At each instance, the guidelines they proposed were thought to be conservative, to err on the

\footnotetext{
${ }^{81}$ D. B. Williams, J. P. Monohan, W. T. Nicholson and J. J. Aldrich, 'Biologic effects studies on microwave radiation', A.M.A. arch. opthal., 54 (1955), 870-872; and their 'Biologic effects studies on microwave radiation. Time and power thresholds for the production of lens opacities by $12 \cdot 3 \mathrm{~cm}$. microwaves', I.R.E. trans. med. elect., ME-4 (1956), 17-22.

${ }^{82}$ T. S. Ely and D. E. Goldman, 'Heat exchange characteristics of animals exposed to $10 \mathrm{~cm}$. microwaves', I.R.E. trans. med. elect., ME-4 (1956), 38-43; and the completed study presented to the first Tri-Service Conference (see footnote 83 below), and reprinted in IEEE Trans. biomed. eng., BME-11 (1964), 123-135.

${ }^{83}$ T. S. Ely and D. E. Goldman, 'Heat exchange characteristics of animals exposed to $10 \mathrm{~cm}$. microwaves', in Evan G. Pattishall (ed.), Proceedings of Tri-Service Conference on Biological Hazards of Microwave Radiation (15-16 July 1957) ARDC TR-58-51; ASTIA Doc. No. AD 115 603, 70. (These proceedings are hereafter cited as 'TS I'.)
} 
side of safety, but still there were doubts. ${ }^{84}$ More research was needed and it was needed rapidly, since by the mid-1950s extremely powerful radar transmitters, such as the project Dewline, were moving from the drawing board to the field. As a result, the decision was made at the level of the Department of Defense, with the advice of an ad hoc planning committee, to centralize and expand greatly its research effort in this area in an attempt to resolve the basic problems. This decision, which was made in late 1955 or early 1956, marks the theoretical beginning of the Tri-Service era, even though the actual research did not begin until $1957 .^{85}$

During the years 1955-56, the Air Force relocated its coordinated biohazards or 'radhaz program', as it was commonly called, from CRC to the School of Aviation Medicine at Randolph Field. Through SAM's research effort, several university investigators were funded, including Hines, Schwan, Justus Lehman, Charles Susskind and Russell Carpenter. The focus of these studies was on ocular and testicular damage and on possible cumulative and nonthermal effects. ${ }^{86} \mathrm{Just}$ as these efforts were getting under way, another directive was issued, bringing the biohazards program back under the control of ARDC, but not at CRC, as before, but at the Rome Air Development Command (RADC). RADC was a logical location for the program since many of the operational problems of radar health and safety resulted from the continuing development of classified high-powered systems. RADC was the Air Force's central location for most of this classified research and development effort. It is under this organization that Colonel George Knauf, the major moving force behind the Tri-Service program, and others of RADC met with scientists, brought together through a contract with The George Washington University, at Griffiss Air Force Base on 31 October and 1 November 1956, for an 'ARDC Microwave Panel' that determined what research ought to be pursued and how it ought to be coordinated and funded. The outcome of this meeting was an extensive, four-year research effort and four Tri-Service conferences, held annually from 1957 to $1960 .^{87}$

The plan of research proposed by RADC was well structured and easily justifiable in light of the military's major concern-determining the exposure level at which hazards could be ex pected. Action was being taken in response to persistent inquiries for more information about the new high-powered equipment being developed. 'Our

\footnotetext{
${ }^{84}$ For a review of the early actions of the military in setting a standard, see George M. Knauf, 'The biological effects of microwave radiation on air force personnel', A.M.A. arch. indust. hygiene, 17 (1958), 49; William Mumford. 'Microwave radiation hazards' (footnote 73), 432; and Steneck et alii (footnote 2). By erring on the side of wafety, the military meant building in a safety factor of 10 (they early on adopted $10 \mathrm{mw} / \mathrm{cm}^{2}$ as an assumed safe level) as opposed to the industrial factors of 100 and 1000 (see footnote 73 alove).

${ }^{85}$ We have been unable to locate documentation that sheds light on the Department of Defense's strategy in undertaking the Tri-Service Program. The sparse illusions during the Tri-Service conferences clearly do not tell the entire story. For example, whereas the Air Force claimed that it had been asked by the Navy to take over the research effort (TS I, 1) at least one person active in the Navy program at the time suggested that the order to transfer activities came 'from above' (private communication, David Goldman). We are continuing to investigate this problem.

${ }^{86}$ For a summary of SAM research activities, see TS I, 6-22.

${ }^{87}$ The reference for the first Tri-Service conference is given in footnore 83 . The proceedings of the other three conferences were published as follows: Evan G. Pattishall and Frank W. Banghart (eds.), Proceedings of the Second Annual Tri-Service Conference on Biological Effects of Microwave Energy $(8,9,10$ July 1958), RADC-TR-58-54, ASTIA Doc. No. AD 131 477; Charles Susskind (ed.), Proceedings of the Third Annual Tri-Service Conference on Biological Hazards of Microwave Radiation Equipments (25-27 August 1959), RADC-TR-59-140, ASTIA Doc. No. AD 234 788; and M. F. Peyton (ed.), Proceedings of the Fourth Annual Tri-Service Conference on Biological Effects of Microwave Radiation Equipments (1961, New York: Plenum Press). (These proceedings are hereafter cited as 'TS II', 'TS III' and 'TS IV' respectively.)
} 
people recognize this situation and ask a very straightforward, reasonable question, "What effect will this energy have on man?" '. Knauf's reply to his own question was equally straightforward: 'At the present moment, we are without an answer to that question' ${ }^{88}$ The objective of the Tri-Service program was to answer this question by selecting a representative range of frequencies for investigation $(200,3,000,10,000$, $24,500,35,000$ megacycles), by looking at evidence of injury to 'living cells, tissues, and intact organisms' from both pulsed and continuous energy sources, and by raising some fundamental problems concerning dosage and the mechanisms of the reactions. To achieve this objective, interdisciplinary teams of researchers would be assembled: 'physicians, electronic engineers, physicists, biologists, and representatives of the other interested bio-sciences' were to be included, and a long list of universities was given that were either in the process of doing research on the biological effects of microwave radiation or planning such research for the newly begun research effort. ${ }^{89}$

The overall results of this research effort, although quite extensive in detail, can be summarized in general terms fairly briefly. The directive that the research teams were given was to expose given species of animals to given microwave frequencies and to describe and account for in as much detail as possible the effects that were seen. To insure that effects were seen, the majority of experiments were conducted as power levels well in excess of the known point at which injuries occurred (above $100 \mathrm{mw} / \mathrm{cm}^{2}$ ). They were also conducted for relatively short exposure times. The typical experiment conducted under the Tri-Service program was one employing short-duration, high-dose radiation. ${ }^{90}$ Under these conditions, effects were seen and described in some detail, thus meeting a portion of the initial objective. Moreover, since the dose levels were in most cases well above the capacities of the animals in question to deal with the increased energy being absorbed, the effects seen were invariably thermal, which is hardly surprising. In comparison with the thermal effects, any nonthermal effects that might have resulted were so insignificant that they would have been masked by the obvious thermal effects. Then, as one final consequence of this research procedure, since the exposure times employed were of relatively short duration (a few minutes over a few weeks or months as compared to actual field conditions which can expose workers for eight hours or more a day for many years), when the dose levels were decreased the effects that had been seen at higher dose levels no longer appeared. This usually happened at or slightly below $100 \mathrm{mw} / \mathrm{cm}^{2}$. As a consequence, based on the research plan adopted by the TriService program, most of the data collected were consistent with the current notion' that all effects were thermal in nature and insignificant at or below $100 \mathrm{mw} / \mathrm{cm}^{2}$. It should be pointed out that even today there is no agreement on whether there are

88 TS I, 39.

${ }^{89}$ TS I, 40.

${ }^{90}$ Although widely used, the terms 'high dose', 'low dose', 'long duration', and 'short duration' have never been given exact definitions. Currently accepted usage, which began to take shape during the TriService era, would equate 'high dose' with power levels above $100 \mathrm{mw} / \mathrm{cm}^{2}$ (leaving the issues of pulsed versus continuous and peak-pulse versus average-pulse unspecified) and 'low dose' as $10 \mathrm{mw} / \mathrm{cm}^{2}$ and below. Exposure times are more difficult to deal with, since some researchers regard week or month-long tests as 'long duration' while others tend to equate 'long' with chronic or continuous exposure. We have adopted common usage with regard to dose levels and clarified duration when it is crucial to an argument. Current debate, particularly in the popular press, over the problem of microwave exposure would be greatly elevated by the adoption of more precise terminology. 
nonthermal effects or even whether the distinction between thermal and nonthermal is a meaningful one.

The flaws in this research plan are apparent but not necessarily reproachable within the conditions under which it was undertaken. Obviously researchers made an error in assuming that when the thermal effects seen at high dose levels disappeared at lower dose levels there were no effects, and particularly no nonthermal effects, at lower dose levels over longer periods of time. To argue that low-dose, chronic effects do not exist, one has to conduct low-dose, chronic experiments, and these simply were not undertaken to any significant extent under the Tri-Service program. But it is important to remember that the research techniques and precedents that existed at the time the Tri-Services program began did not encompass many of the procedures that are needed to discover the dose levels that present a hazard. The now common techniques for studying mutagenesis, carcinogenesis, and tetratogenesis were in their infancy in the late 1950s. Environmental studies and the notion of environmental impact were just beginning to emerge as important issues. Moreover, the problem of microwave exposure was seen primarily as one that concerned the military and its defense contractors; planners were not looking ahead to the general saturation of the environment with this new form of energy. And finally, if experiments were speeded up by increasing dose rates, this too is not unexpected. The military needed answers as soon as possible in order to avoid potential hazards of large-scale proportions. Their eyes were not fixed on long-range, subtle effects that might result years in the future.

\section{Safety standards and the ending of the Tri-Service program}

The information the military began receiving from its researchers within a year after the RADC program began soon allowed an answer to Knauf's initial question about hazards. As his remarks at the beginning of the second Tri-Service conference confidently noted, 'I think this might be a good time to say that up to date there has not been any effect produced or even hinted at power levels which remotely approach our established maximum safe exposure level' ${ }^{91}$ The high-dose, short-duration experiments conducted by most of the experimenters confirmed the view that nonthermal effects did not exist and that exposures of $10 \mathrm{mw} / \mathrm{cm}^{2}$, the initial guideline established, were safe. Two more years of research served only to reinforce this view. Knauf's remarks at the beginning of the fourth Tri-Service conference in 1960 echoed those of two years earlier: 'I am indeed pleased to say that up to today we have not seen any research data which shake our faith in the validity of this arbitrary safe exposure level [of $10 \mathrm{mw} / \mathrm{cm}^{2}$ ] which we sponsored some five years ago'.92 Shortly after this remark was made, the Tri-Service program came to an end.

Who made the ultimate decision to end the Tri-Service program is not clear. The active researchers in the field were not convinced that they knew all that there was to know about biological effects and therefore had no reason to end their investigations. Even those such as Schwan, who supported the majority view that no dangers existed at the $10 \mathrm{mw} / \mathrm{cm}^{2}$ level, were anxious and expecting to continue their work when the program came to an end. ${ }^{93}$ However, by like token, once the initial problem

\footnotetext{
91 TS II, 6.

92 'T' IV 9 .

${ }^{93}$ Private communication (Schwan).
} 
of hazardous exposure levels had been resolved, which it clearly had been in the minds of those policy makers whose views are known and in the minds of many scientists, the military had no reason to continue in the business of funding basic research. As long as controls could be established to keep personnel from being exposed to dangerous $\left(100 \mathrm{mw} / \mathrm{cm}^{2}\right.$ and above) levels of microwave radiation, it mattered little to the military sponsors of the scientific research what effects might ensue at these levels or the mechanisms of such effects. The military was interested in information that could be applied to operations and once this information became available they directed their attention to more pressing issues.

In brief, the probable logic of the decision to end the Tri-Service program, as too the logic of the research program itself, is understandable from a policy point of view. It is not, however, as easily understood from a scientific point of view. Many of the scientists who reported their findings at the Tri-Service conferences clearly felt that they were not in complete control of the situation. The calls for additional work, duplication, and better techniques represent a fairly common theme that runs throughout the proceedings. ${ }^{94}$ From a scientific point of view, even the data supporting the majority view was not the solid, replicated data that one would like to have in making a decision that supposedly rests on scientific fact.

Then, too, there were data presented at the Tri-Service conferences that tended to cast doubt on the majority view concerning nonthermal effects as well as low-level exposure. Very little of this data provided hard evidence that definitely contradicted the majority view. For example, Ely and Goldman tempered their reported findings of testicular degeneration in rats at $5 \mathrm{mw} / \mathrm{cm}^{2}$ with the observation that the degeneration was due to subtle thermal effects, and like hot baths, was neithei: cumulative nor irreversible. ${ }^{95}$ However, from a scientific point of view, this data should have provided an opportunity for the active exchange of ideas that is vital to the advance of science.

As the research effort progressed under the Tri-Service program, data that did not fit with the prevailing views began to accumulate. In research first reported at the third Tri-Service conference and later published in extended form, Russell Carpenter reported cumulative effects of microwave exposure in the formation of cataracts in rabbits. These opacities formed at powers as low as $80 \mathrm{mw} / \mathrm{cm}^{2}$, for a one-hour exposure over a period of nineteen days. Although he had not extended his investigations to the $10 \mathrm{mw} / \mathrm{cm}^{2}$ level or below, Carpenter noted the need for such studies since cumulative effects at those levels were suggested by his research. ${ }^{96}$ Sven Bach and his associates at the U.S. National Institute for Neurological Diseases reported, also at the third Tri-Service conference, that neurological (behavioral) changes could be produced in primates by microwave radiation and that these changes were perhaps not due to thermal effects. ${ }^{97}$

Similar data continuted to accumulate during the fourth Tri-Service conference. Samuel Gunn and colleagues of the University of Miami reported the possibility of nonthermal effects in the testicles of rats at power levels of $250 \mathrm{mw} / \mathrm{cm}^{2}$. ${ }^{98}$ Bach and

94 Steneck et alii (footnote 2).

95 TS I, 64-75.

${ }^{96}$ TS III, 279; and R. L. Carpenter, D. K. Biddle and C. A. Van Ummersen, 'Opacities in the lens of the eye experimentally induced by exposure to microwave radiation', I.R.E. trans. med. elect., ME-7 (1960), 152-157.

97 TS III, 82-92.

98 TS IV, 99-116. 
others, now with the Biophysics and Radiobiology Divisions, U.S. Army Medical Research Laboratory, Fort Knox, Kentucky, reported changes in human gamma globulin that seemed to be frequency-dependent rather than dependent on heating or average power absorbed. ${ }^{99}$ Clair Van Ummersen, of Tufts University, who had originally worked with Carpenter, believed that nonthermal effects of microwaves had an effect on the development of chick embryos. ${ }^{100}$ Finally, in a very solid and cautiously formulated study, Milton Zaret and Merril Eisenbud of the Departments of Ophthalmology and Industrial Medicine, New York University Medical Center, found that an occular study of people exposed to microwaves pointed to related effects. These effects were not so great as to be classed as cataracts. However, 'statistically significant increases in the occurrence of posterior polar defects, luminescence, and early opacification of the lens were found in the exposed group as compared to the control group of personnel. The data suggest further that the frequency of defects may be dependent upon relative severity of exposure to microwaves'. ${ }^{101}$

The net effort of these findings was to bring gradually to the fore two crucial and largely ignored issues-the effects, if any, of chronic, low-dose exposures and the problem of mechanism. Several other key studies, not reported at the Tri-Service conferences, contributed to this shift in emphasis. In 1959, researchers at the Mayo Clinic working with pulsed rather than continuous-wave diathermy machines, reported observing a phenomenon that was commonly known as pearl-chain formation. The pearl-chain effect occurred when short-waves or, in this case, microwaves caused fat globules in diluted milk to line up in a chain-like arrangement. How heat could cause this effect was difficult to explain. ${ }^{102}$

Similar effects, apparently not explicable from a strictly thermal standpoint, were reported in 1959 and 1960 by John Heller and others at the New England Institute for Medical Research in Ridgefield, Connecticut. Heller's group reported that at low levels, continuous electromagnetic fields caused unicellular organisms to 'line up'. Similar to the pearl-chain formation, this effect nonetheless varied in that it took place in living organisms and constrained their movements. Moreover, the formations varied, sometimes causing north-south alignments (running perpendicular to the microwave field) to be observed and sometimes east-west (parallel to the field), depending upon the frequency. ${ }^{103}$

The extensions of these observations brought the possibility of genetic changes into question. Microscopic examinations of immobilized Paramecia 'showed that certain asymmetric cytoplasmic inclusions were oriented when the electromagnetic field was impressed and reverted at once to their original position when the field was released'. Such changes raised the possibility of influencing 'certain structures or molecular aggregates within the cell', which in turn led to the belief that 'genetic material might be affected by such fields'. ${ }^{104}$ A similar conclusion had been suggested in an earlier paper published by Heller in Nature. Growing garlic root tips

${ }^{99}$ TS IV, 117-134.

${ }^{100}$ TS IV, 201-220.

101 TS IV, 303.

${ }^{102}$ A. Wildervanck, K. G. Wakim, J. F. Herrick and F. H. Krusen, 'Certain experimental observations on a pulsed diathermy machine', Arch. phys. med., 40 (1959), 45-55.

${ }^{103}$ A. A. Teixeira-Pinto, L. Nejelski, J. Cutler and J. Heller, 'The behavior of unicellular organisms in an electromagnetic field', Exptl. cell res., 20 (1960), 548-564.

${ }^{104}$ Ibid., 554, 558 . 
were placed in distilled water in a field generated by two insulated electrodes. No increase of the water temperature resulted when the field was turned on, but upon examination twenty-four hours later after a five-minute exposure to the field, the garlic root tips showed chromosomal abnormalities. These included 'linear shortening of chromosomes, pseudochiasmata, amitotic division, bridging, and irregularities in the chromosomal envelope. The effects noted mimicked those produced by ionizing radiation and $c$-mitotic substances' ${ }^{105}$

However, it took more than a limited number of inexplicable findings to get research moving again in the wake of the termination of the Tri-Service program and the earlier near abandonment of most microwave diathermy studies. Research did, of course, continue on a reduced level, funded by ONR, the Army, and other government and private agencies. But massive funding did not return to this field until after microwave ovens came into widespread use in industry and private homes, color televisions grew in popularity along with a host of new electronic gadgetry, and it was discovered that the Russians were bombarding our embassy in Moscow with microwave radiation at the same time that they were pursuing a very active research program on low-level, chronic effects. These events would, however, prompt the field of research on the biological effects of microwave radiation to develop in new ways, whose history must at this point be left for a later study.

\section{Conclusions}

Looking back at the years of research leading to and culminating in the TriService program, some later commentators have discerned the outlines of productive scientific activity effectively pursuing its proper ends while others have seen the beginnings of a conspiracy to suppress the truth that has grown and become more insidious ever since. ${ }^{106}$ Which of these two views is correct is difficult to judge. The accumulation of data over the past two decades strongly suggests that research should not have been as sharply curtailed in 1960 as it was. The data that conflicted with the prevailing view of the late 1950s may not be explicable in the gross thermal mechanisms then assumed to be responsible for all effects. Thus, it now seems that more work should have been undertaken at precisely the moment that research funds were being withdrawn from this field. By like token, we have found no clear evidence to suggest that those setting policy in the late $1950 \mathrm{~s}$ made projections from the scattered data that cast doubt on the standard view and foresaw difficulties that they then endeavored to conceal. More likely, those policy makers, who were unquestionably concerned primarily with the problem of military personnel and not the general public, felt on the basis of existing data and the controllable nature of microwave exposure that they did have the situation well in hand by 1960 and therefore made the decision to redirect funds and energies to problems of more pressing military urgency. Thus, the ultimate appropriateness of the policy decisions in this area depends on what is deemed as 'appropriate' and on this, even today, there is little agreement.

${ }^{105} \mathrm{~J}$. H. Heller and A. A. Teixeira-Pinto, 'A new physical method of creating chromosomal aberrations', Nature, 183 (1959), 905-906.

${ }^{106}$ Two opposing assessments of the Tri-Service era can be found in Brodeur (footnote 2), 32-36; and Sol Michaelson, 'The Tri-Service program: a tribute to George M. Knauf, USAF (MC)', IEEE Trans. MTT-19 (1971), 131-146. 
There is, however, another more limited way to judge the development of research on the biological effects of microwave radiation and that is as science rather than policy. Regardless of the social aims of the research scientists involved and their supporting agencies, they were all in the business of pursuing scientific inquiry, and on this basis they can be judged, because as research scientists one assumes that they must have had as one of their goals understanding the workings of nature. The question that arises then is: did they proceed to this understanding in a professional and scientific manner? Our assessment, after a fairly exhaustive study of the literature, is that they did not. The reasons for this are complex, although they all rest on one overriding factor, the institutional structure within which the scientific research was carried out.

The major scientific question that underlays all work on the biological effects of microwave (and more broadly radio-wave) radiation is the impact that this form of electromagnetic energy has on living systems. In an ideal world, this is the primary problem that the pure research scientist would pose were s/he to approach this field de novo. However, from the early 1920 s on, this question was seldom asked in its pure form. Almost as soon as effects were discovered, it became the applied effects, not the pure effects, that were the primary point of focus, and thereby the interest in the nonapplied natural process was reduced to a place of secondary importance. Pre-war researchers studied therapeutic effects, post-war researchers studied hazards. There is very little evidence throughout of an interest in the microwave-tissue interaction as such and apart from the products of interaction.

The reason for the applied nature of the research undertaken is obvious. The major funds that were available to support research on biological effects came in the vast majority of cases from organizations interested in results, not pure research. Before the war, medical schools were the primary supporters while after the war the focus shifted slowly but dramatically to the military. With the possible exception of Heller's work on unicellular organisms and Schwan's theoretical approach, almost all other work in the area was done for and served the interests of one or more funding agencies interested in the application of effects and not the effects themselves. Within this context it is little wonder that more research was not done on biological effects per se.

The impact of this institutional setting on the research pursued is significant and goes well beyond the simple rephrasing of the basic scientific questions asked from pure to applied terms. The medical setting within which diathermy-related research initially grew up played an important role in directing the thermal-nonthermal debate decidedly toward the thermal solution. Nonthermal effects, within the medical context, came too close to medical quackery; the undefined, in mechanistic terms, too easily became the uncontrolled and the uncontrollable, and so a conscious effort was made to discount all but thermal effects. The anomalistic findings, which in a detached atmosphere of pure scientific research could have sparked legitimate debate, in the applied context found little room and so were downplayed and discounted.

Once set, the bias toward the acceptance of only thermal mechanisms (and by implication only higher-dose-level effects) exerted a definite influence on this field of research through the Tri-Service era. The dictum first posed in the 1930s-the burden of proof lies on those who believe in other than thermal effects-remained the rule of the $1940 \mathrm{~s}$ and $1950 \mathrm{~s}$. Especially during the Tri-Service program, thermal projects were easily understood and readily funded, but nonthermal research was 
much more difficult to sell and would remain so until the issue of possible nonthermal 'application' arose in the $1960 \mathrm{~s} .{ }^{107}$ In sum, there can be no doubt that the institutional setting within which research on the biological effects of electromagnetic radiation grew up exerted a definite intellectual influence on the content of that research.

A second impact of the institutional setting on this field of research is in the area of method. As late as the fourth Tri-Service conference, when the problems were supposedly well in hand, some of the most important papers presented ended with the very basic and seemingly obvious point that no sure conclusions could be drawn until the problems of dosimetry were solved and techniques for replication improved. ${ }^{108}$ Why such calls for improved method were necessary even after four years of intense activity is clear. The problems of dosimetry had not been worked out by 1960 nor had there been any serious attempt at replication. But what allowed such serious flaws in scientific method to creep in in the first place? Again, it is the institutional structure that is at least in part the cause.

Because research in this area from the yery beginning focused on particular applications and not the isolated natural phenomenon, the controlling factor in dealing with dose became the wave-generating machine and not the electromagnetic wave itself. In the early medical literature, dose - when reported(!)- was synonymous with a particular diathermy machine placed at a specific distance and turned on for some duration. For the medical research being undertaken, little more was needed, since it was the effect of the machine on biological tissue that was of interest. The actual dose that the subject or patient received from the machine did not matter, as long as the effects seemed therapeutic. As a result, from the beginning this field of research tended to ignore biophysical concerns and problems relating to dosimetry.

Following World War II and in response to the need to determine the level at which injuries could be expected dosimetric concerns did become more important. But the research resulting from these concerns did not keep pace with nor was it well integrated with the more specifically biological research. Because dosimetry was regarded by the military as primarily an operational problem-how much exposure did personnel actually experience in the field-they tended not to assign this research to the same research groups investigating hazards. Dosimetry problems were discussed in separate reports during the Tri-Service conferences and not related at all specifically to the hazards experiments. For their part, those pursuing the hazards studies remained more firmly grounded in the biomedical context that characterized the earlier years of research on diathermy and in the process passed lightly over dosimetric issues. As a result, when the time came for the comparison of data there was very little data to compare. The conditions under which experiments were conducted varied so much and were so inexactly known that replication simply was not and could not have been achieved. The very specific goals of the applied research (applied in the sense that it was directed toward the solution of problems that concerned existing technology) did not permit the sort of questioning to go on and internal development that would have led to more exacting scientific methodology.

\footnotetext{
107 The manner in which nonthermal effects came to be regarded as worth investigation will form the subject of further research. We do know (from private communication with Heller and Allan Frey) that research on nonthermal responses was not readily funded in the late $1950 \mathrm{~s}$.

${ }^{108}$ TS III, 279-291.
} 
For these and other more subtle reasons, it seems clear that the institutional structure that planned and supported research on the biological effects of microwave radiation did influence the way this field developed as a science. The internal logic of science did not dictate the course of history. If it had, Szymanowski and Hicks's discovery of the attenuation of bacterial toxins or. Heller's reports on the alignment of single-celled organisms might have become the topics of conferences instead of fever therapy and radar. Research on each has perhaps more bearing on our understanding of nature than the dose level at which cataracts form in rabbits or the depth to which radio waves penetrate in an aching muscle. That such conferences were not held attests to the importance societal values exert on the development of science.

That societal values do exert pressures on and influence the development of science is important to recognize. The products of scientific inquiry that emerge from years of research on a topic such as the biological effects of microwave radiation represent more than abstract knowledge. Because of the institutional structure that nurtures their development these products represent knowledge filtered through and shaped by the values and interests of society (or a segment of society) as well as information about nature. Scientific information is, in brief, value-laden and not value-free, and it must be considered as such when it is used to make decisions about policy. Information that has been derived by the scientific process must be treated with the same discerning eye as information that comes from social theorists, theologians, and humanists, because it too is shaped by-perhaps to a lesser extent but nonetheless shaped by-its environment. If this fact were more widely recognized, it would make policy making a more responsive process and at the same time help keep the environment for scientific research as pollution free as possible.

\section{Acknowledgements}

Support for this project has been provided by a joint grant from the NSF-Ethics and Values in Science and Technology and the NEH-Science, Technology, and Values programs. Local support was provided by the University of Michigan Collegiate Institute for Values and Science.

The authors are all at the University of Michigan. Harold J. Cook is a Ph.D. candidate in history, Nicholas H. Steneck an associate professor of history, Arthur J. Vander a professor of physiology, and Gordon L. Kane a professor of physics. 